\title{
Development and validation of an HPLC method for stability evaluation of nystatin
}

\author{
Ana Paola Prata Cione*, Márcio José Liberale, Paulo Marcos da Silva
}

Bioagri Laboratories

\begin{abstract}
A liquid chromatography method for evaluating the stability of Nystatin (Nys) in an ointment was developed and validated, since the traditional pharmacopeial microbiological methods are unable to indicate stability. The stress experiments showed that Nys was found to significantly degrade in alkaline and acidic conditions and also under oxidative stress. Lower levels of degradation were detected under heat and with the sample exposed to Xenon light. Resolutions higher than 2 for Nys and degradation products (DP) chromatographic peaks were achieved by using an Inerstil ODS-3 column, isocratic elution with methanol:water and UV detection at $305 \mathrm{~nm}$. The system was found to be linear over a range of 102 to $310 \mathrm{IU} \mathrm{mL} \mathrm{m}^{-1}$ and proved precise, since the $\mathrm{RSD}(\%)$ was $0.24 \%$ for the six replicates tested. The method also exhibited good levels of recovery (from $98.24 \%$ to $100.74 \%$ ). Therefore, the validation fulfilled pharmacopeial requirements and the procedure was found to be reliable, precise, accurate and selective for determination of Nys and its degradation products.
\end{abstract}

Uniterms: Nystatin/stability analysis. Forced degradation/stress. High performance liquid chromatography/qualitative analysis.

Um método indicador de estabilidade por cromatografia líquida foi desenvolvido e validado para a análise de Nistatina (Nys) em uma pomada, uma vez que os métodos microbiológicos tradicionais não têm a habilidade de serem indicadores de estabilidade. A nistatina degradou significativamente em condições alcalinas e ácidas e também em meio oxidante. Quando a amostra foi exposta a luz de xenônio, foram observados menores níveis de degradação. A resolução entre os picos cromatográficos de Nys e seus produtos de degradação (PD) foi maior que 2, utilizando-se uma coluna Inerstil ODS-3, eluição isocrática com metanol: água e detecção no UV em $305 \mathrm{~nm}$. O sistema foi linear entre a faixa de $102 \mathrm{a}$ $310 \mathrm{UI} \mathrm{mL}^{-1}$ e preciso uma vez que o DPR(\%) foi de $0,24 \%$ entre as seis replicatas testadas. Além disso, o método exibiu bons níveis de recuperação (de 98,24\% a 100,74\%). Consequentemente, considera-se que a validação atendeu a todos os requisitos farmacopêicos e o método pode ser considerado confiável, preciso, exato e seletivo para determinação de Nys e seus produtos de degradação.

Unitermos: Nistatina/análise de estabilidade. Degradação forçada/estresse. Cromatografia líquida de alta eficiência/análise qualitativa.

\section{INTRODUCTION}

Nystatin is a substance, or a mixture of two or more substances (Figure 1), produced by the growth of Streptomyces noursei (Streptomycetaceae). It has a potency of at least 4400 units per $\mathrm{mg}$, or when intended for use in extemporaneous preparation, at least 5000 units per $\mathrm{mg}$. Some physical chemistry characteristics of nystatin inclu-

*Correspondence: A. P. P. Cione. Bioagri Laboratórios. Rod. Rio Claro-Piracicaba - 13412-000 - Piracicaba - SP, Brazil. E-mail: a.cione@bioagri.com.br

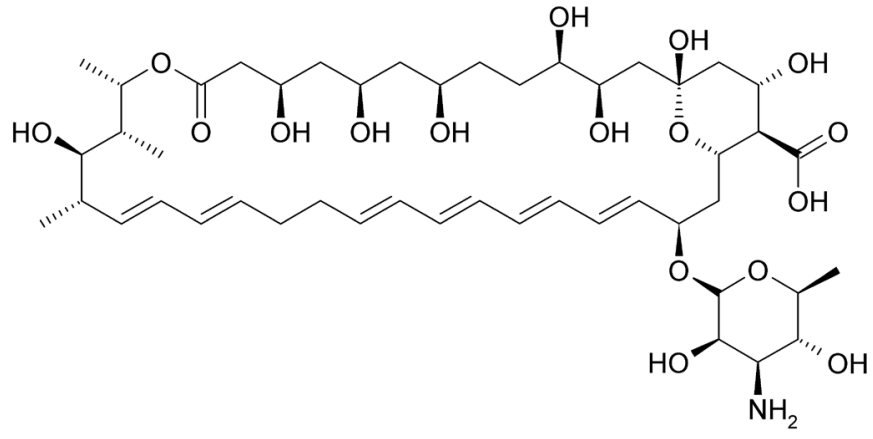

FIGURE 1 - Chemical structure of nystatin. 
de: yellow to light tan, hygroscopic powder, with an odour suggestive of cereals, being affected by long-term exposure to light, heat and air. Nys is a polyene antifungal antibiotic used for the prophylaxis and treatment of candidiasis of the skin and mucous membranes (Martindale, 2002).

Pharmacopeial methods for Nys assay, as well for other antibiotics, are traditionally microbiological (USP, 2008; EP, 2008) and yield the potency of the drug.

However, the use of microbiological methods is limited or not applicable when it becomes necessary to monitor the degradation of a drug product when submitted to stability studies, for example.

The regulatory agency (ANVISA) currently requires that analytical methods employed for drug products should be stability-indicating methods (ANVISA RE 01/05; ANVISA RE 899/03; Giannellini et al., 2005; Kumar et al., 2007; Munro et al., 2001), i.e., selective/ specific for detecting not only the main active principle but also the impurities and degradation products that may emerge during short (accelerated) or long-term stability studies (ANVISA RE 01/05). Indeed, the use of this kind of method is strongly recommended when the principle active is indicated as unstable in the specialized literature (Martindale, 2002; Merck Index, 2001).

It is important to note that the purpose of stability testing is to provide evidence on how the quality of a drug substance or drug product varies over time under the influence of a variety of environmental factors such as temperature, humidity and light. Stability testing permits the establishment of recommended storage conditions, retest periods, and shelf-lives (ICH, 2003).

Forced degradation, or stress testing, is carried out under harsher conditions than those used for accelerated stability testing. Laboratory procedures should cause the potential drug to degrade under specific conditions (acid and base hydrolysis, light/photostability, peroxide oxidation and temperature).

Stability-indicating-methods (SIM) are satisfactorily developed during forced degradation tests, with the main objective of evaluating the purity of both main active principle and degradation products. The analytical method obtained in this way will be able to detect such substances wherever they appear during stability studies.

Additionally, quantitative determination of degradation products can be done by using analytical standards when available. If these are unavailable, the determinations by $\%$ area are acceptable or in other cases, collecting of peaks by preparative HPLC or identification by HPLCMS are valid.

Although several HPLC methods can be found in the literature for Nys analysis (Lavra, 2008; Llabot,
2007; Matusch, 1994; Ostrosky-Zeichner, 2001), to date, no stability-indicating-methods for Nys determination in drug products have been described. The aim of this study was to establish an analytical method which is specific and selective for Nys analysis in a commercial ointment product. This method was duly validated according to ANVISA regulations (ANVISA RE 899/03).

\section{EXPERIMENTAL}

\section{Reagents and solutions}

Analytical grade $\mathrm{HCl}$ (Merck), Dichloromethane (Tedia), Sodium hydroxide (Nalgon) and Hydrogen peroxide (Synth), and HPLC grade Methanol (Tedia), were used. Dilutions, when necessary, were made to the desired concentrations for use in sample preparations. All reagents used were of analytical grade while the solvents were of chromatographic purity.

\section{Standard solution}

A solution of analytical standard (Nystatin USP

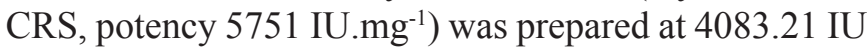
$\mathrm{mL}^{-1}$ (calibration solution A) for calibration purposes (see Table I). Two solutions at around $200 \mathrm{IU} \mathrm{mL}^{-1}$ (calibration solutions $\mathrm{B}$ and $\mathrm{C}$ ) were prepared to test the system suitability of the method. The solvent used for dilution was methanol.

\section{Calibration curve}

Dilutions from solution A were made to prepare calibration solutions (Table I).

TABLE I - Calibration curve solutions

\begin{tabular}{lcc}
\hline$\%)$ & $\begin{array}{c}\text { Volume of solution } \\
\mathrm{A}(\mathrm{mL})\end{array}$ & $\begin{array}{c}\text { Final concentration } \\
\left(\mathrm{IU} \cdot \mathrm{mL}^{-1}\right)^{*}\end{array}$ \\
\hline 50 & 0.125 & 102.08 \\
75 & 0.185 & 151.08 \\
100 & 0.250 & 204.16 \\
125 & 0.320 & 261.33 \\
150 & 0.380 & 310.32 \\
\hline
\end{tabular}

$*_{\text {final volume }}=5 \mathrm{~mL}$

\section{Sample preparation}

\section{Extraction}

Approximately $1.0 \mathrm{~g}$ of a commercial sample 
TABLE II - Forced degradation samples

\begin{tabular}{lll}
\hline Stressing condition & Stressing solution/diluent & Incubation temperature/time exposure \\
\hline Acid hydrolysis & $0.1 \mathrm{~mol} \mathrm{~L}-1 \mathrm{HCl}$ & $60^{\circ} \mathrm{C} / 120$ hours \\
Base hydrolysis & $0.1 \mathrm{~mol} \mathrm{~L}-\mathrm{NaOH}$ & $60^{\circ} \mathrm{C} / 120$ hours \\
Peroxide oxidation & $\mathrm{H}_{2} \mathrm{O}_{2} 0.3 \%(\mathrm{v} / \mathrm{v})$ & $60^{\circ} \mathrm{C} / 120$ hours \\
Light exposure & Methanol & Xenon lamp at $250 \mathrm{~W} \mathrm{~m}^{-2}$ attached to ID 65 filters \\
Heat exposure & Methanol & $60^{\circ} \mathrm{C} / 120$ hours \\
\hline
\end{tabular}

$\left(100000 \mathrm{IU} \mathrm{g}^{-1}\right)$ was weighed and transferred to a volumetric flask of $50 \mathrm{~mL} .5 \mathrm{~mL}$ of dichloromethane was added and the solution was homogenized. The volume was then completed with methanol and the final solution vortexed for 1 minute. This solution was filtered through a $0.45 \mu \mathrm{m}$ PVDF filter. $1 \mathrm{~mL}$ was transferred to a volumetric flask of $10 \mathrm{~mL}$ and the volume was made up with the diluent to be used in the forced degradation study.

\section{Forced degradation sample preparation (Specificity Assay)}

An aliquot of $1 \mathrm{~mL}$ of the extracted sample was transferred to a volumetric flask and the volume was completed with the stressing solution/diluent listed in Table II. The resultant samples were incubated in an oven at $60{ }^{\circ} \mathrm{C}$ or in a photostability chamber for up to 48 hours - aliquots from these samples were then analyzed by HPLC-DAD.

The main objective during the development of the chromatographic conditions was to achieve peak purity of Nys, i.e. to guarantee the selectivity of the analytical method for this active principle.

\section{Chromatographic conditions}

For Nys determination, an Agilent model 1100 HPLC device with DAD detection at $305 \mathrm{~nm}$ was used. The chromatographic column used was a Phenomenex Inertsil ODS $-3-100 \AA$ ( $250 \times 4.6 \times \mathrm{mm}, 5 \mu \mathrm{m})$ in an oven at $40^{\circ} \mathrm{C}$. The mobile phase was constituted by methanol: water $(75: 25 \mathrm{v}: \mathrm{v})$ and the flow rate was $1.0 \mathrm{~mL} \mathrm{~min}^{-1}$. The injection volume was $10 \mu \mathrm{L}$. The retention time of Nys was around 7 minutes and the total run time was 15 minutes.

\section{Validation}

After the initial establishment of the chromatographic conditions, the pharmacopeial validation requirements were followed using system suitability, linearity, LoQ, precision (repeatability and intermediate precision), accuracy and robustness assays.

The isomers of Nys were forced to co-elute and quantification was based on a single chromatographic peak.

\section{Data Evaluation and Statistical Analysis}

Degradation products were monitored and reported based on HPLC area percent values. Statistical analysis was limited to arithmetic mean and relative standard deviation (RSD).

\section{Control of Bias}

Each sample was analyzed in duplicate and all data obtained was expressed as arithmetic mean, standard deviation and relative standard deviation.

\section{RESULTS AND DISCUSSION}

\section{Specificity of forced degradation samples}

The analysis of the placebo - prepared in the same manner as the commercial samples- under the proposed chromatographic conditions showed no interference to Nystatin retention time. Table III shows the results of the analysis of each stressed sample, after 24 and 48 hours.

TABLE III - Time of exposure of samples to forced degradation

\begin{tabular}{lcc}
\hline \multirow{2}{*}{$\begin{array}{l}\text { Stressing } \\
\text { Condition }\end{array}$} & \multicolumn{2}{c}{$\begin{array}{c}\text { Percentage of degradation (\%) } \\
\text { Time of exposure }\end{array}$} \\
\cline { 2 - 3 } & 24 hours & 48 hours \\
\hline Acid hydrolysis & 88.2 & - \\
Base hydrolysis & 100.0 & - \\
Peroxide & 57.7 & - \\
oxidation & & \\
Light exposure & 8.9 & 19.8 \\
Heat exposure & 47.3 & - \\
\hline
\end{tabular}

The proposed chromatographic conditions yielded pure peaks of Nys and degradation products, since the purity factor given by the equipment software was higher than 980.

Figures 2 and 3 present representative chromatograms of the analytical standard of Nys and also of the acidic hydrolysis stressed sample, respectively. The retention 


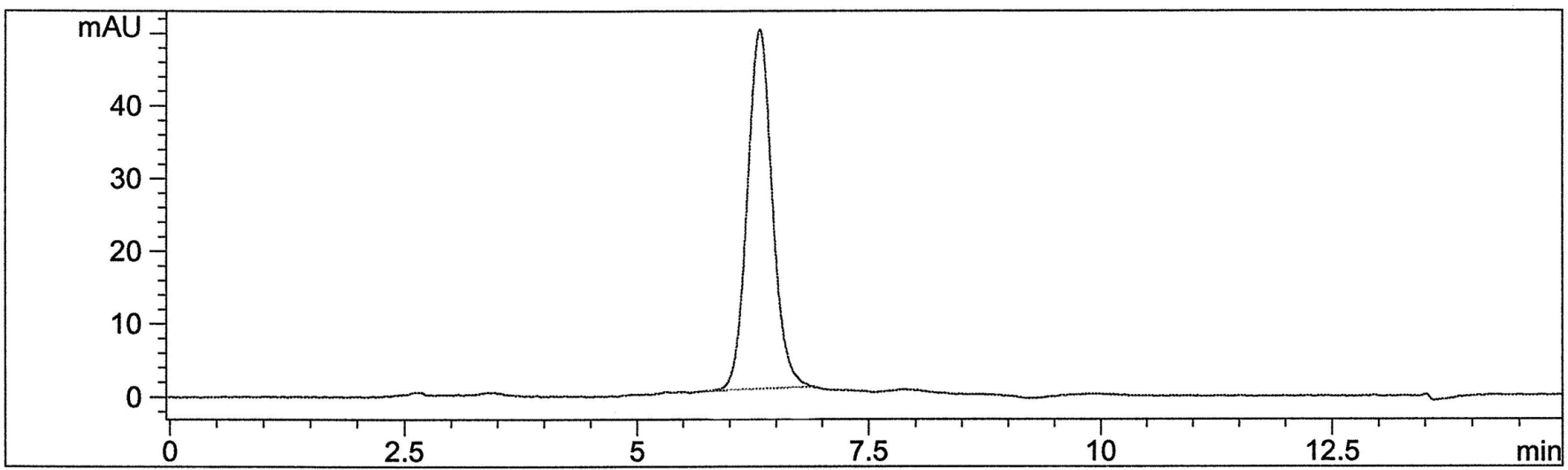

FIGURE 2 - Chromatogram of a solution of analytical standard of Nystatin [205 IU.mL-1] (refer to Chromatographic Conditions).

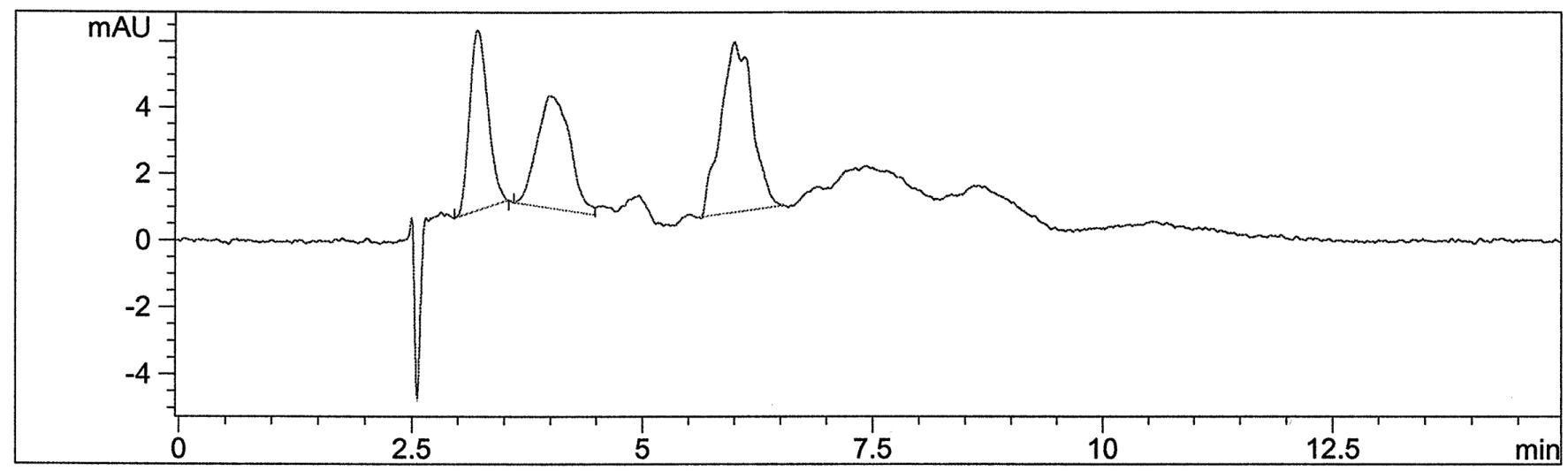

FIGURE 3 - Chromatogram of acid hydrolysis sample after 24 hours of incubation (refer to Chromatographic Conditions).

time of Nys was around 6.3 minutes. Due to the strong degradation of Nys (almost 88\%) in the stressed sample, the chromatographic peak is lower compared to the analytical standard. Other peaks at $3.2 \mathrm{~min}$ and $4.00 \mathrm{~min}$ were evidenced, corresponding to the degradation products (DP) of Nys formed due to hydrolysis in acidic media. A higher level of degradation was also found in the alkaline hydroxide sample $(100 \%)$. The sample exposed to peroxide stress achieved around $58 \%$ of degradation while those exposed to heat and Xenon light displayed $48 \%$ and $9 \%$ of degradation, respectively. These samples were considered suitable for the method development, since different degradation products at different levels were achieved.

\section{System suitability}

The RSD of six injections of solution $\mathrm{C}$ was lower than $2 \%$ and the comparison with the unique injection of solution $\mathrm{C}$ was also lower than $2 \%$, indicating that the method is adequate. Also, the plates for the column $(\mathrm{N})$ were higher than 2500 and the USP tailing was lower than 2.0.

\section{Linearity}

The linearity was tested in the concentration range of 102 to $310 \mathrm{IU} \mathrm{mL}^{-1}$. The correlation coefficient determined by the best fit from least-squares treatment was $=0.99993$. The response factor was constant at all concentration levels.

\section{LoQ}

LoQ was determined as the concentration in which the ratio signal noise (standard deviation calculation at baseline) and height of the chromatographic peak (signal) was around 10 which was found to be $10.21 \mathrm{IU} \mathrm{mL}^{-1}$.

\section{Precision}

\section{Repeatability and intermediate precision}

The precision of the method was evaluated based on the results of the analysis of six samples from analyst A at day 1 and the results from intermediate precision from 
TABLE IV - Percentage of recovery for Nystatin

\begin{tabular}{lcccc}
\hline Level (\%) & $\begin{array}{c}\text { Nominal concentration of } \\
\text { Nystatin }\left(\mathrm{IU} \mathrm{mL}^{-1}\right)\end{array}$ & $\begin{array}{c}\text { Determined concentration of } \\
\text { Nystatin }\left(\mathrm{IU} \mathrm{mL}^{-1}\right)\end{array}$ & \multicolumn{2}{c}{ Recovery } \\
\hline 80 & 164.7 & 165.5 & 100.5 & Mean $(\%) \pm s$ \\
\hline 162.7 & 164.3 & 101.0 & \\
& 162.9 & 164.2 & $100.7 \pm 0.3$ \\
100 & 213.9 & 216.5 & 101.2 & $100.2 \pm 1.0$ \\
& 214.5 & 215.0 & 100.2 & \\
120 & 214.4 & 212.8 & 99.3 & $98.2 \pm 0.6$ \\
& 254.6 & 251.8 & 98.9 & \\
& 254.3 & 249.1 & 97.9 & 97.9 \\
& 254.8 & 249.5 & $99.7 \pm 1.3$ \\
\hline
\end{tabular}

TABLE V - Robustness

\begin{tabular}{lccc}
\hline Parameter & \multicolumn{3}{c}{ Nystatin [IU mL $\left.\mathrm{mL}^{-1}\right]$} \\
\cline { 2 - 4 } & Mean & RSD & Recovery (\%) ${ }^{*}$ \\
\hline Flow $\left(0.8 \mathrm{~mL} \cdot \mathrm{min}^{-1}\right)$ & 107161 & 0.1 & 100.9 \\
Flow $1.2 \mathrm{~mL} \cdot \mathrm{min}^{-1}$ & 106505 & 0.2 & 100.3 \\
$73 \%$ methanol: $27 \%$ water & 107005 & 0.1 & 100.8 \\
$77 \%$ methanol: $23 \%$ water & 107014 & 0.2 & 100.8 \\
Column oven at $35^{\circ} \mathrm{C}$ & 106665 & 0.9 & 100.5 \\
Column oven at $45^{\circ} \mathrm{C}$ & 107608 & 0.2 & 101.4 \\
\hline
\end{tabular}

*reference sample $\left[106155.70 \mathrm{IU} \mathrm{mL}^{-1}\right]$ was considered $100 \%$ compared with the actual value.

six other samples / analyst B at day 3 .

The values demonstrated by their means (104839 $\mathrm{IU} \mathrm{g}^{-1}$ for repeatability and $105192 \mathrm{IU} \mathrm{g}^{-1}$ for intermediate precision, respectively) and relative standard deviations (RSDs, calculated from the results of the six samples and twelve samples, were lower than $2 \%$ ) that the method can be considered precise.

\section{Accuracy of the method}

The accuracy of the method is the degree of conformity of a measured or calculated value with its actual or specified value. Table IV shows the results of the accuracy (recovery) assay tested for three concentration levels of Nystatin spiked in placebo.

Recovery results for all samples were within the $95 \%$ to $105 \%$ range, which is considered acceptable according to pharmacopeial and official guidelines (USP, 2008; ANVISA RE 899/03).

\section{Robustness}

The robustness of the method was tested by al- terations on flow, proportion of organic solvent in the mobile phase and temperature of the column. The mean results [IU mL ${ }^{-1}$ ] of two injections, RSD and recovery for each tested condition compared to a reference sample (injected in the initial chromatographic conditions) are shown in Table V.

The criteria were all accepted for this validation stage, since the RSD between the injections in each analytical condition were lower than $2 \%$ and the recovery values were within $95 \%-105 \%$.

\section{CONCLUSIONS}

The results for linearity, selectivity, precision (repeatability and intermediate precision), accuracy and robustness of the method were acceptable according to pharmacopeias and official guidelines. Therefore, the analytical method proposed can be considered a specific and valid HPLC- Stability-indicating method for analysis of Nys and degradation products for application in quality control processes and stability studies. 


\section{REFERENCES}

BRASIL, Agência Nacional de Vigilância Sanitária Resolução (ANVISA). Recomendação técnica Available at: $<$ http://www.anvisa.gov.br/medicamentos/recomenda/ fotoestabilidade.pdf $>$. Accessed on: 21 oct. 2009.

BRASIL, Agência Nacional de Vigilância Sanitária Resolução (ANVISA). RE $\mathrm{n}^{\circ}$ 899, de 29 de maio de 2003. Guia para a Validação de Métodos Analíticos e Bionalíticos. Diário Oficial da União Poder Executivo, Brasília, 02 de jun. 2003. Available at: $<$ http://e-legis.anvisa.gov.br/leisref/public/ showAct.php?mode=PRINT_VERSION\&id=15132>. Accessed on: 21 oct 2009.

BRASIL. Agência Nacional de Vigilância Sanitária Resolução (ANVISA). Resolução RE n ${ }^{\circ}$ 1, de 29 de julho de 2005 Guia para a realização de estudos de estabilidade. Diário Oficial da União; Poder Executivo, Brasília, 01 de agosto de 2005. Available at: $<$ http://e-legis.anvisa.gov.br/leisref/public/ showAct.php?id $=18109 \&$ mode $=$ PRINT_VERSION $>$. Accessed on: 21 oct. 2009.

EUROPEAN PHARMACOPOEIA. 6.ed. Strasbourg: Council of Europe, 2007. p.2534-2536.

GIANNELLINI, V.; SALVATORE, F.; BARTOLUCCI, G.; CORAN A. C.; BAMBAGIOTTI-ALBERTI M. A validated HPLC stability-indicating method for the determination of diacerhein in bulk drug substance. J. Pharm. Biom. Anal., v.39, n.3-4, p.776-780, 2005.

INTERNATIONAL CONFERENCE ON HARMONISATION. Q2(R1) Validation of Analytical Procedures: Text and Methodology. Available at: <http://www.ich.org/LOB/ media/MEDIA417.pdf $>$. Accessed on: 15 jun. 2009.

INTERNATIONAL CONFERENCE ON HARMONISATION. Q1A(R2) Stability Testing of New Drug Substances and Products. Available at: <http://www.ich.org/LOB/media/ MEDIA419.pdf $>$. Accessed on: 15 jun. 2009.

KUMAR V.; BHUTANI H.; SINGH S. ICH guidance in practice: Validated stability-indicating HPLC method for simultaneous determination of ampicillin and cloxacilin in combination drug products. J. Pharm. Biom. Anal., v.43, n.2, p.769-773, 2007.
LLABOT, J. M; ALLEMANDI D. A; MANZO, R. H; LONGHI, M. R. HPLC method for the determination of nystatin in saliva for application in clinical studies. J.Pharm. Biom. Anal., v.45, n.3, p.526-30.2007.

LAVRA, Z. M. M.; SONEGO, F.; SILVA, R. M. F.; MEDEIROS, F. P. M.; de. Rev. Bras. Cienc. Farm. [online] v.44, n.4 [citado 2009-06-16], p. 637-643, 2008. Available at: $<$ http:// www.scielo.br/scielo.php?script=sci_arttext\&pid=S1516>. Accessed on: 15 jun. 2009.

THE MERCK INDEX: Encyclopedia of chemical, drugs and biologicals. 30.ed. New Jersey: Merck, 2001. p.9806.

MUNRO J. S.; WALKER T. A., Ranitidine hydrochloride: development of an isocratic stability-indicating highperformance liquid chromatographic separation. $J$. Chromatogr., v.914, n.1-2 A, p.13-21, 2001.

OSTROSKI-ZEICHNER, L.; BAZEMORE, S.; PAETZNICK, V. L.; RODRIGUEZ, J. R.; CHEN, E.; WALLACE, T.; COSSUM, P.; REX, J. H. Differential antifungal activity os isomeric forms of Nystatin. Antimicrob. Agents Chemother. v.45, n.10, p.2781-786, 2001.

SAUER, B.; MATUSCH R. High-performance liquid chromatographic separations of Nystatin and their influence on the antifungal activity. J. Chromatogr. A, v.672, n.1-2, p.247-253, 1994.

SWEETMAN, S.C. (Ed.). Martindale. The complete drug reference. (35.ed.) London: Pharmaceutical Press, 2002. p.392.

UNITED STATES PHARMACOPEIA. 31.ed. Rockville: United States Pharmacopeial Convention, 2008. p.27872788.

Received for publication on $24^{\text {th }}$ June 2008 Accepted for publication on $19^{\text {th }}$ October 2009 